\title{
Effect of Planting Density on Root Lodging Resistance and Its Relationship to Nodal Root Growth Characteristics in Maize (Zea mays L.)
}

\author{
Shengqun Liu ${ }^{1}$, Fengbin Song ${ }^{1}$, Fulai Liu ${ }^{2}$, Xiancan Zhu ${ }^{1}$ \& Haibo $\mathrm{Xu}^{3}$ \\ ${ }^{1}$ Northeast Institute of Geography and Agroecology, Chinese Academy of Sciences, Changchun 130102, Jilin \\ Province, People's Republic of China \\ ${ }^{2}$ Department of Agriculture and Ecology, Faculty of Sciences, University of Copenhagen, Taastrup, Denmark \\ ${ }^{3}$ College of Pharmacy, Jilin University, Changchun 130102, People's Republic of China \\ Correspondence: Shengqun Liu, Northeast Institute of Geography and Agroecology, Chinese Academy of \\ Sciences, Changchun 130012, Jilin Province, People's Republic of China. Tel: 86-431-8554-2225. E-mail: \\ sqliu1976@live.cn
}

Received: September 18, 2012 Accepted: September 25, 2012 Online Published: November 15, 2012

doi:10.5539/jas.v4n12p182

URL: http://dx.doi.org/10.5539/jas.v4n12p182

\begin{abstract}
Increase of planting density has been widely used to increase grain yield in maize. However, it may lead to higher risk of root lodging hence causing significant yield loss of the crop. The objective of this study was to investigate the effect of planting density on maize nodal root growth characteristics and to analyse their relationships to root lodging resistance. Field experiment was conducted in 2010 and 2011, using two maize varieties, Zhengdan 958 (ZD) and Xianyu 335 (XY), under three planting densities, viz., 4.50, 8.25 and 12.00 plants $\mathrm{m}^{-2}$. The results showed the root failure moment, an indicator of root lodging resistance, was significantly affected by the planting density, the maize variety, as well as the crop developmental stages, and was decreased with increasing planting density. The number and the average diameter of the roots on the upper internodes (phytomer 5 to 8 ) were decreased with increasing planting density, whereas the maize variety had little effects on those variables. On the contrary, the root angle was less responsive to planting density but was significantly affected by the variety being that XY had larger root angle than did ZD. The root failure moment was linearly positively correlated with the total root number and the average root diameter on the upper internodes, indicating that a greater root number and a larger root diameter are important traits for enhancing root lodging resistance in maize plants.
\end{abstract}

Keywords: nodal root, planting density, root failure moment, root lodging

\section{Introduction}

Root lodging is caused by the failure of root anchorage, which results in straight, unbroken culms leaning from the crown (Pinthus, 1974). It has long been a problem in crop cultivation causing great reductions in crop yield and quality (Crook \& Ennos, 1994; Carter \& Hudelson, 1988; Easson et al., 1993; Jedel \& Helm, 1991; Stanca et al., 1979; Stamp \& Kiel, 1992). Increasing planting density is often used to increase maize yield in China (Feng et al., 2010). However, greater planting density may lead to higher risk of root lodging. In sunflower (Helianthus annuus L.), Sposaro et al. (2008) found that root failure moment and root plate diameter decrease with increasing the crop population density. In wheat (Triticum aestivum L.), Berry et al. (2000) reported the seeding rates of wheat reduce when plant anchorage strength increase. However, in maize (Zea mays L.) the effects of planting density on the susceptibility of the crop to root lodging remain largely unknown.

It is well recognized that both plant characteristics and weather conditions are important in determining the susceptibility of a crop to root lodging. Apart from the role of water and nutrient uptake, roots are essential for lodging resistance of the plants (Hetz et al., 1996). Root characteristics such as root diameter, root number, and the angle of root are major factors influencing root lodging (Guingo \& Hébert, 1997; Ennos \& Crook, 1993a, 1993b; Pinthus, 1967; Hébert et al., 1992; Hébert et al., 2001). 
High planting density increases the intraspecific competition, and which will inevitably affect some shoot and root growth (Hébert et al., 2001; Tetio-Kagho \& Gardner, 1988). Thus, due to increased competition between the individual plants, the root system and its anchoring ability could become weak under high planting densities. However, to data very little information is available regarding how root traits of maize plants respond to high planting density (Stamp \& Kiel, 1992). And mass and height of gravity center of shoot was changed, and requirement of anchoring accordingly changed during the reproductive period. However how root respond the anchoring requirement and how lodging resistance respond the increasing of planting density during the reproductive period of maize are not satisfactory enough.

The root lodging often occurs when heavy rains accompanied by strong winds, and rains and winds are usually unevenly distributed over a specific area (Melchinger et al., 1986), therefore using percentage of lodged plants in field to measure the root lodging resistance of maize genotypes is unreliable (Kamara et al., 2003). Therefore, research on the susceptibility of crop to root lodging can only be done artificially by inducing external force to evaluate the resistance of the plants to root lodging. The root failure moment $(R f m)$ is an indicator of root lodging resistance. However, in maize the effects of planting density on the $R f m$ and relationship between $R f m$ and root characteristics remain largely unknown. In addition, susceptibility to root lodging may vary among maize genotypes, thus selecting or breeding maize cultivars for higher resistance to root lodging can be an effective approach to improve yield under high planting densities (Hébert et al., 2001). Moreover, understanding the response of root traits to increased planting densities will be useful in exploring the key mechanisms causing root lodging.

In the present study, two maize varieties, Zhengdan 958 and Xianyu335, which are widely cultivated in China, were tested for their susceptibility to root lodging under different planting densities. This study was used the method of artificial root lodging under different planting densities, and by artificially inducing external force to evaluate the resistance of the plants to root lodging. Our objectives were to investigate how the root failure moment changed during late growth stage of maize and major root traits in response to different planting density and their relationships to root lodging resistance. The knowledge obtained will be useful for developing novel management strategies to enhance crop resistance to root lodging thereby improving crop yield under high planting densities.

\section{Materials and methods}

\subsection{Materials and Experimental Setup}

The experiment was carried out in field conditions in 2010 and 2011 at the Agricultural Experimental Station of Northeast Institute of Geography and Agroecology, Chinese Academy of Sciences, located in Dehui $\left(125^{\circ} 33^{\prime} \mathrm{E}\right.$, $44^{\circ} 12^{\prime} \mathrm{N}$ ), Jilin Province, China. The mean annual air temperature in the area is $4.4^{\circ} \mathrm{C}$. The average annual precipitation at the experimental station is about $520.2 \mathrm{~mm}$, with $70 \%$ of the precipitation falls between June and August. The soil at the experimental sites is black soil with a organic matter of $26.90 \mathrm{~g} \mathrm{~kg}^{-1}$, total N of $1.20 \mathrm{~g} \mathrm{~kg}^{-1}$, total $\mathrm{P}$ of $1.06 \mathrm{~g} \mathrm{~kg}^{-1}$, total $\mathrm{K}$ of $16.87 \mathrm{~g} \mathrm{~kg}^{-1}$, Availability $\mathrm{N}$ of $118.9 \mathrm{mg} \mathrm{kg}^{-1}$, Availability P of $18.02 \mathrm{mg} \mathrm{kg}^{-1}$, Availability $\mathrm{K}$ of $111.1 \mathrm{mg} \mathrm{kg}^{-1}$ and $\mathrm{pH}$ of 6.6 .

Two maize varieties, Zhengdan 958 (ZD) and Xianyu335 (XY), were planted 3 May 2010 and 2 May 2011. The plots were fertilized with $60 \mathrm{~kg} \mathrm{~N} \mathrm{ha}^{-1}, 60 \mathrm{~kg} \mathrm{Pha}^{-1}$ and $60 \mathrm{~kg} \mathrm{~K}^{-1}$ before sowing. Three planting densities namely; low density (LD) with 4.50 plants $\mathrm{m}^{-2}$, medium density (MD) with 8.25 plants $\mathrm{m}^{-2}$, and high density (HD) with 12.00 plants $\mathrm{m}^{-2}$ were used. Each treatment was replicated three times, in total 18 plots were laid out in the field. In all plots, the distance between rows was kept at $75 \mathrm{~cm}$. Each plot consisted of ten rows (including two border rows) and each with $15 \mathrm{~m}$ long. Additional $\mathrm{N}$ fertilizer $\left(\mathrm{NH}_{4} \mathrm{NO}_{3}\right)$ was applied on June 25 and July 20 at $22.9,42.0$ and $61.0 \mathrm{~kg} \cdot \mathrm{ha}^{-1}$ for the LD, MD and HD treatment, respectively, ensuring the individual plants received a similar amount of $\mathrm{N}$ under different planting densities. The plants were well-irrigated during the whole experimental period to avoid water deficits.

A self-made instrument, similar to that described by Sposaro et al. (2008), was used to measure the root lodging force on 80, 90,100, 110 and 120 days after sowing (DAS). The soil of the experimental plot was pre-wetted $48 \mathrm{~h}$ before conducting the measurements. The horizontal pushing test was performed on 24 plants per variety ( 3 replicates with 8 plants each). The rows were oriented south to north direction and the plants were lodged towards the west to mimic the effects of the southeast winds that prevail during summer in the area. The root lodging measurements were performed after removing the leaves and sheaths of the plants and the stems were cut at $0.4 \mathrm{~m}$ above the ground to avoid obstruction of the aerial parts with neighboring plants. The plants of treated plots were manually pushed at $0.20 \mathrm{~m}$ above the ground perpendicular to the direction of the row. (Fouéré et al., 1995). 
The maximal force $\left(F_{\max }\right)$ of the push, determined by an ergometer (HF-500N, China), and the angle between the slanting stem and the soil surface $(\alpha)$ upon exertion of the maximal force, measured with a protractor, were recorded.

The root failure moment $R f m$ (in Nm) was calculated by the following formula:

$$
R f m=\mathrm{F}_{\max } \times \cos (\alpha) \times \mathrm{h}
$$

Where $\mathrm{F}_{\max }$ is the maximal force (in N) of the push and $\mathrm{h}$ is $0.2 \mathrm{~m}$.

On 100 DAS, after the horizontal push test, the plants were uprooted with a spade. Adherent soil was washed away with running water. The number, the diameter and the angle of the roots on the $5^{\text {th }}$ to the $8^{\text {th }}$ internodes were measured. In this paper, mesocotyl, the first and second layer of roots at the bottom of the stem of plant were designated the first (P1), second (P2) and third phytomer (P3) in turn, and so on (Girardin et al., 1986; Sylvain, 1993). The nodal roots at the bottom of the stem were designated axile root (Feix et al., 2002). Only the elongated roots that grew into the soil were considered when the number of roots on internodes P8, P7, P6, and P5 were measured. The average angle of the roots on those internodes, defined as the deflection from the vertical, was measured at a point $5 \mathrm{~cm}$ from axile root-internode junction using a protractor (Pinthus, 1967). The root diameters on internodes P8, P7, P6 and P5 were measured at a point $5 \mathrm{~cm}$ from the axile root-internode junction using a digital caliper.

\subsection{Statistical Analysis}

All Statistical analyses of the data were done with the (SPSS Inc., Chicago, IL, USA). Multiple comparisons among the treatments were analyzed with Duncan's multiple range test.

\section{Results}

\subsection{Root Failure Moment (Rfm) as Affected by Planting Density and Maize Variety}

The planting density, variety, and the crop developmental stages all had significanteffects on $R f m$ (Tables 1 and 2). The $R f m$ was the highest in $\mathrm{LD}$, followed by $\mathrm{MD}$, and the lowest in HD for both maize varieties across all developmental stages (Table 1). Between the two maize varieties, ZD had significantly higher $R f m$ than XY. In addition, there were significant interactions between the variety and the planting density on $R f m$ (Table 2). It was shown that $R f m$ of ZD was more sensitive to increase of planting density than did XY particularly at earlier developmental stages, i.e., on 80 and 90 DAS. Concerning the effects of the developmental stages, there was a clear tendency that the $R f m$ increased from earlier to later developmental stages for both maize cultivars under all planting densities (Table 1).

\subsection{The Number of Nodal Root on the Upper Internodes}

Maize variety had no effect on the number of root on the P7 and P8 internodes (Figure 1a-b); whereas it had significant effect on the number of root on the $\mathrm{P} 5$ and $\mathrm{P} 6$ internodes, being that $\mathrm{ZD}$ possessed significantly higher number of root than did XY (Figure 1c-, d). On the contrary, planting density significantly affected the number of root on the P7 and P8 internodes (Figure 1a-, b) but had no effect on the number of nodal root on the P5 and P6 internodes (Figure 1c-, d). Nevertheless, across all internodes there was a clear tendency that the root number decreased with increasing planting density. In addition, except for P7 internode, there were significant interactive effects between planting density and variety on the number of root (Figure 1). On the P8 internode, the number of root was slightly higher for $\mathrm{ZD}$ than $\mathrm{XY}$ at $\mathrm{LD}$, whereas at MD there reverse was the case (Figure 1a). On the P5 and P6 internodes, though for both varieties there was a trend that the root number decreased with increasing planting density, the response was more pronounced for ZD than for XY (Figure 1c, d).

\subsection{The Average Angle of Nodal Roots on the Upper Internodes}

Maize variety had significant effect on the average root angle of roots on all the four internodes across the three planting densities, being that XY had significantly larger root angle than ZD (Figure 2). Across the two varieties, planting density only significantly affected the root angles for the roots on P5 internodes (Figure 2d). Among the four internodes, variety and planting density had significant interactive effects on the root angle on P6 being that the root angle was slightly increased with increasing planting density for ZD, but kept unchanged for XY (Figure 2c).

\subsection{The Average Diameter of Nodal Roots on the Upper Internodes}

Except for the roots on the P5 internode, planting density significantly affected the average root diameter of roots on the other three internodes across the two varieties, being that the average root diameter decreased with increasing planting density (Figure 3). Maize variety had on effects on the average root diameter (Figure 3a-c) 
except for the roots on the P5 internode where ZD had significantly greater root diameter than XY (Figure 3d). Only for the roots on the P8 internodes, there was a significant interactive effect between maize variety and planting density on the average root diameter being that at $L D$ the average root diameter was slightly higher for XY than for ZD, whereas under MD the opposite was true (Figure 3a).

Table 1. Root failure moment (in Nm) for two maize varieties (ZD and XY) as affected by three different planting densities at different developmental stages

\begin{tabular}{|c|c|c|c|c|c|c|}
\hline \multirow{2}{*}{ Varieties } & \multirow{2}{*}{ 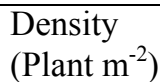 } & \multicolumn{5}{|c|}{ DAS } \\
\hline & & 80 & 90 & 100 & 110 & 120 \\
\hline \multirow{3}{*}{ ZD } & 4.50 & $22.65 \pm 3.12$ & $26.28 \pm 1.94$ & $26.32 \pm 1.68$ & $25.46 \pm 1.56$ & $26.39 \pm 2.08$ \\
\hline & 8.25 & $10.91 \pm 1.22$ & $13.32 \pm 1.31$ & $15.75 \pm 1.81$ & $15.51 \pm 1.14$ & $16.20 \pm 1.29$ \\
\hline & 12.00 & $7.79 \pm 1.54$ & $10.62 \pm 1.48$ & $13.50 \pm 2.20$ & $12.92 \pm 1.46$ & $11.71 \pm 0.88$ \\
\hline \multirow{3}{*}{$X Y$} & 4.50 & $14.77 \pm 1.31$ & $19.50 \pm 1.96$ & $22.89 \pm 1.94$ & $20.99 \pm 2.37$ & $23.13 \pm 2.66$ \\
\hline & 8.25 & $10.57 \pm 1.24$ & $12.57 \pm 1.39$ & $14.09 \pm 1.65$ & $14.60 \pm 1.59$ & $15.76 \pm 1.67$ \\
\hline & 12.00 & $8.70 \pm 1.18$ & $10.16 \pm 1.38$ & $10.23 \pm 1.39$ & $9.88 \pm 1.32$ & $9.39 \pm 1.27$ \\
\hline
\end{tabular}

Table 2. Out-put of three-way ANOVA for the effect of the variety (V), the planting density (D), and the developmental stages $(\mathrm{S})$ and their interactions $(\mathrm{V} \times \mathrm{D}, \mathrm{D} \times \mathrm{S}$ and $\mathrm{V} \times \mathrm{D} \times \mathrm{S})$ on root failure moment $(R f m)$.

\begin{tabular}{ll}
\hline Factor & $R f m$ \\
\hline $\mathrm{V}$ & $* * *$ \\
$\mathrm{D}$ & $* * *$ \\
$\mathrm{~S}$ & $* * *$ \\
$\mathrm{~V} \times \mathrm{D}$ & $* *$ \\
$\mathrm{D} \times \mathrm{S}$ & $\mathrm{ns}$ \\
$\mathrm{V} \times \mathrm{D} \times \mathrm{S}$ & $\mathrm{ns}$
\end{tabular}

$*, * *, * * *$ indicate significance level at $P \overline{\leqslant 0.05, P \leqslant 0.01,} P \leqslant 0.001$, respectively. And ns indicate no significance.
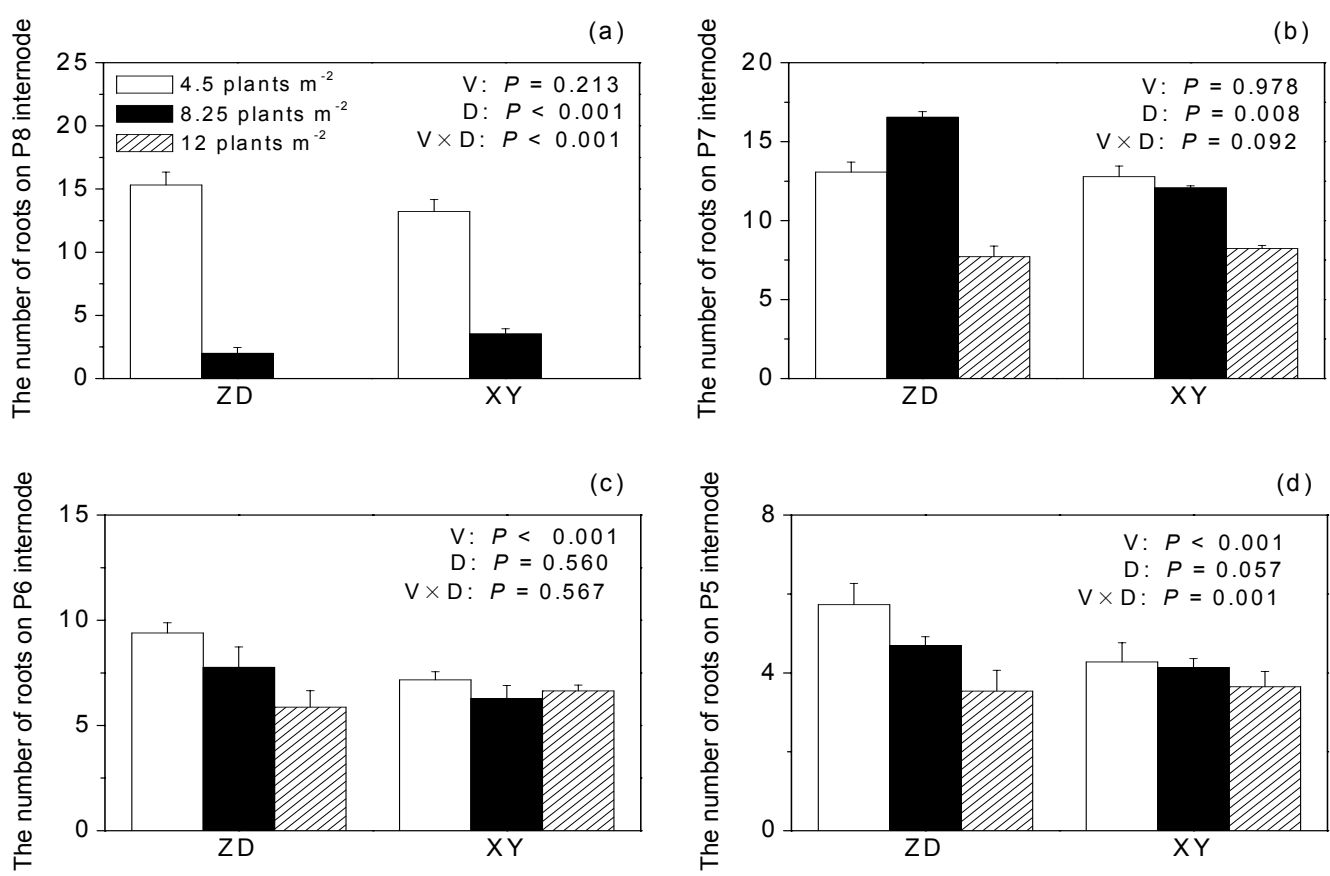

Figure 1. The number of root on the upper internodes of two maize varieties (ZD and XY) under three planting densities $\left(4.50,8.25\right.$ and 12.00 plants $\left.\mathrm{m}^{-2}\right)$. Error bars indicate S.E. $(\mathrm{n}=3)$ 


\subsection{Relationships of Root Failure Moment (Rfm) to Root Number and Root Diameter on the Upper Internodes}

To analyze the relationships between the $R f m$ and root traits, linear regressions between the $R f m$ and the total root number and the weighed-average root diameter on the upper internodes for both maize varieties at 100 DAS were performed (Figure 4). It was clear that there were significant positive linear relationships between the $R f m$ and the root number as well as the weighed-average root diameter on the upper internodes (Figure 4).
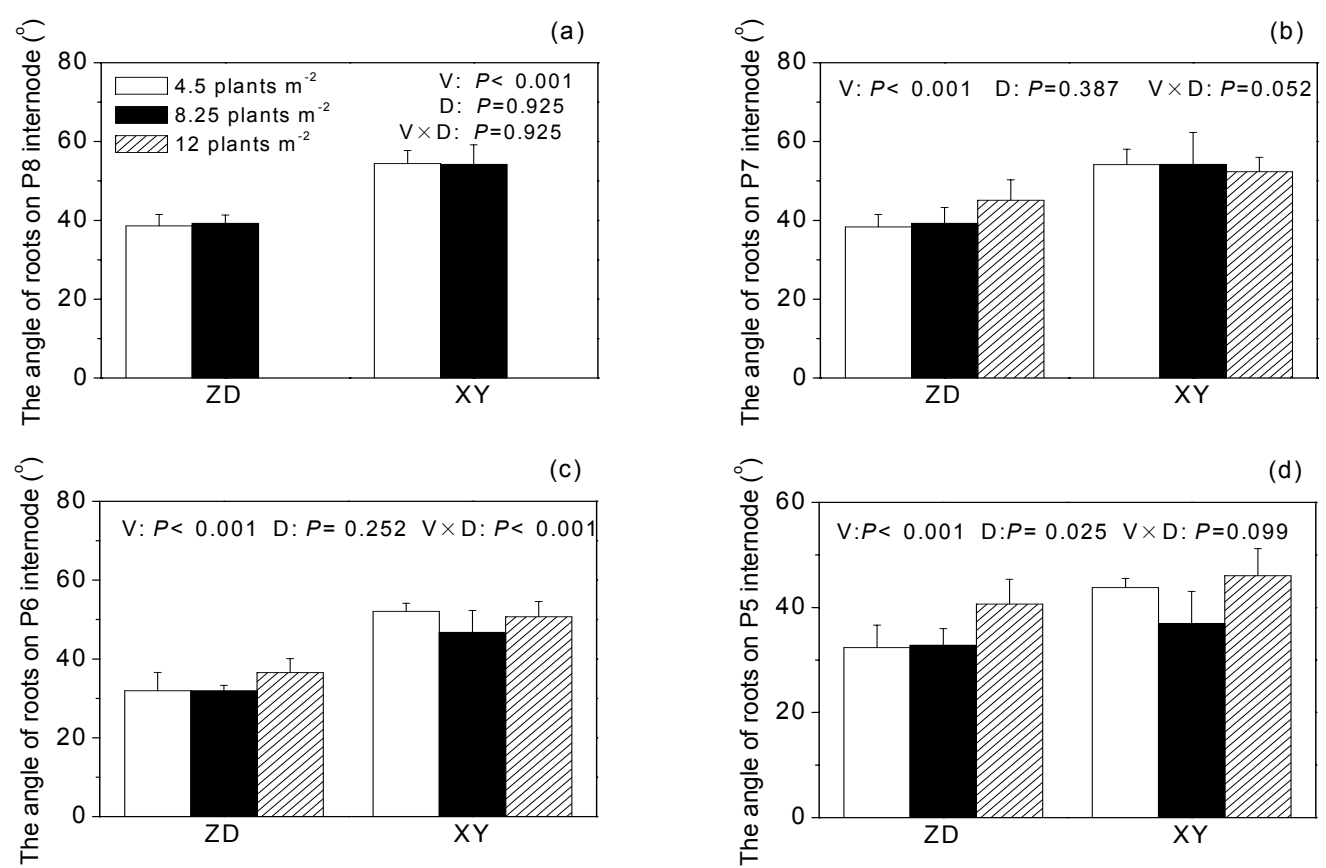

Figure 2. The average root angle of roots on the upper internodes of two maize varieties (ZD and XY) under three different planting densities $\left(4.50,8.25\right.$ and 12.00 plants $\left.\mathrm{m}^{-2}\right)$. Error bars indicate S.E. $(\mathrm{n}=3)$

(a)

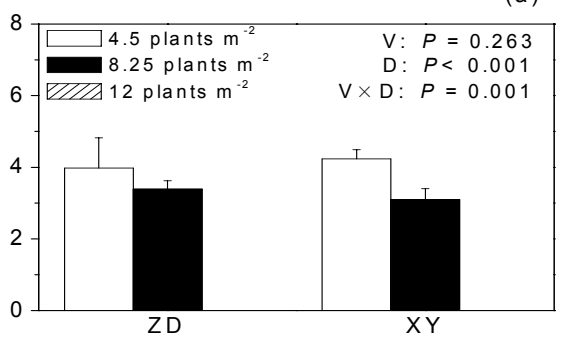

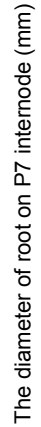

(b)

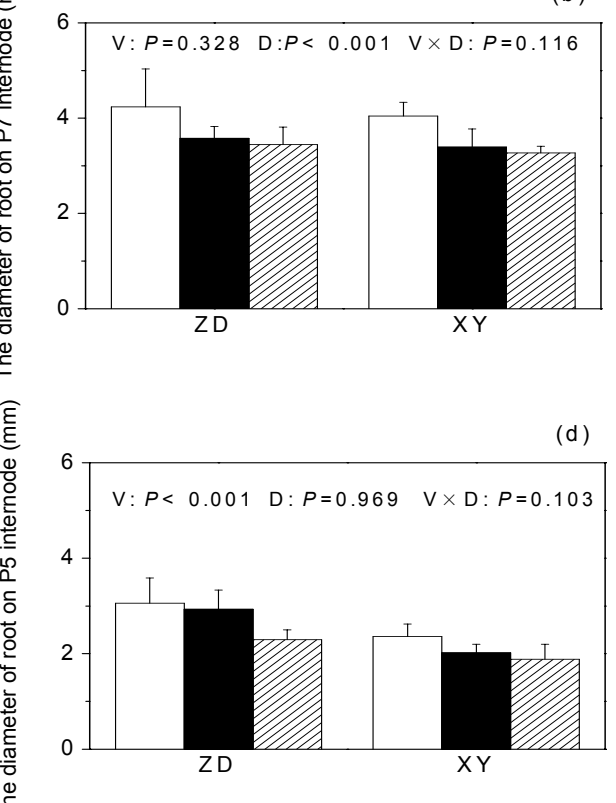

Figure 3. The average root diameter of roots on the upper internodes of two maize varieties (ZD and XY) under three planting densities $\left(4.50,8.25\right.$ and 12.00 plants $\left.\mathrm{m}^{-2}\right)$. Error bars indicate S.E. $(\mathrm{n}=3)$ 

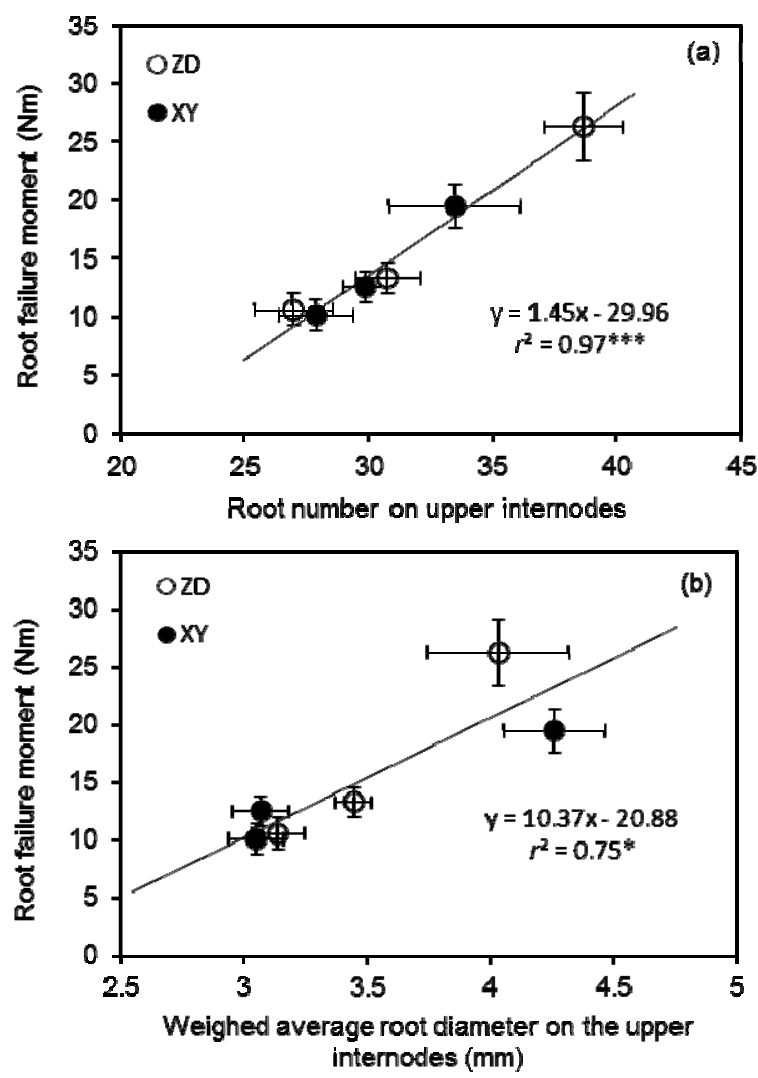

Figure 4. Relationships between root failure moment $(R f m)$ and the total number (a) and the weighted average of diameters (b) of rootsonP5, P6, P7 and P8 internodes at 100 DAS of two maize varieties at three planting densities.

Error bars indicate S.E. $(\mathrm{n}=6)$

\section{Discussion}

The results of this paper clearly showed that with increasing planting density increased root lodging susceptibility of maize by the lowered $R f m$ values (Table 1). This is in good agreement with earlier findings in wheat (Berry et al., 2004) and sunflower (Sposaro et al., 2008). In addition, it was also noticed that the two maize varieties differed significantly in the $R f m$ values showing that $\mathrm{ZD}$ was more resistant to root lodging than $\mathrm{XY}$ particularly at low planting density (Table 1). Moreover, there were significant interactions between maize varieties and planting densities on $R f m$ (Table 2) being that the $R f m$ of ZD was more sensitive to increase of planting density than did XY (Table 1). At present, increase of planting density are being widely used for increasing grain yield in maize (Feng et al., 2010). However, based on the our results it was obvious that increase of planting density could lead to higher risk of root lodging which may cause significant yield loss of the crop (Berry et al., 2004; Sposaro et al., 2008). Therefore, to increase grain yield in maize via increasing planting density, the planting density must be kept within a reasonable range in order to minimize the risk of root lodging. Besides, selection of maize varieties for greater resistance to root lodging could be an efficient approach for obtaining higher grain yield under high planting density. To do so, a better understanding of the characteristics of nodal roots and their relationships to root lodging resistance is required.

It is known that the roots and shoots play important roles in determining the susceptibility of a crop to root lodging (Berry et al., 2000; Hébert et al., 1992). During the late jointing-booting stage, due to increased shading of light at higher plant population the growth rate of the plants at HD was much less than that at $\mathrm{LD}$, as indicated by the delayed appearance of the upper leaves of the ears and the postponed flowering time (data not shown). Considering the appearance of newly rooted stalk nodes is closely associated with the appearance of new leaf tips and collars (Zur et al., 1992), the roots on the upper internodes (i.e., P5 to P8) appeared later at HD that those at LD. Compared to the upper internodes, the time of root appearance on the lower internodes (i.e. P1 to P4) was much earlier; and planting density has minor effect on the growth of these roots. Therefore, the growth characteristics of the roots from P1 to P4 internodes were not determined in this study. Furthermore, the roots on the upper internodes possess more and larger meta-xylem and their mechanical tissue is much better developed than those on the lower 
internodes, thus they contribute much more significantly to the anchoring of the plant (Hoppe et al., 1986; Stamp \& Kiel, 1992). Here, the root number, root diameter, and root angle of the upper internodes P5 to P8 were determined in two maize varieties under three planting densities during grain-filling stage (i.e., 100 DAS). The results showed that the root number and the average root diameter were decreased with increasing the planting density; while both were less affected by the maize variety (Figures 1 and 2). On the contrary, the root angle was almost unresponsive to planting density but was significantly affected by the maize variety, being that XY had larger root angle than did $\mathrm{ZD}$ (Figure 3). Collectively, it is seemingly that root quantitate traits such as the number and the diameter are more sensitive to change of planting density; whereas root qualitative traits like root angle is varietal specific and unresponsive to change of planting density.

It is well known that the root growth characteristics are closely related to their ability to resist root lodging (Kevern \& Hallauer, 1983; Penny, 1981; Sposaro et al., 2008; Stamp \& Kiel, 1992). In the present study, we have clearly shown that, across the two maize varieties and three planting densities, the $R f m$ was linearly positively correlated with the total root number and the weighed-average root diameter on the upper internodes (Figure 4), indicating that a greater root number and a larger root diameter are important traits for enhancing root lodging resistance in maize plant. Earlier studies have also indicated that wider root spread angles are associated with greater resistance to root lodging (Pinthus 1967; Guingo \& Hébert, 1997); however, this was not the case in the present study that ZD had a smaller root angle but possessed significantly greater $R f m$ than XY which had a larger root angle. It is clear that the significance of the root qualitative traits such as root angle in contributing to root lodging resistance merits further investigations.

\section{Conclusions}

In this study, our results showed that planting density significantly affected the nodal root growth characteristics including root number and root diameter but had very little effect on root angle; whilst maize variety did not affect root number and diameter but significantly influenced root angle. The $R f m$ was linearly positively correlated with the total root number and the average root diameter on the upper internodes, indicating that a greater root number and a larger root diameter are important traits for enhancing root lodging resistance in maize plants.

\section{References}

Berry, P. M., Griffin, J. M., Sylvester-Bradley, R., Scott, R. K., Spink, J. H., Baker, C. J., \& Clare, R.W. (2000). Controlling plant form through husbandry to minimise lodging in wheat. Field Crops Research, 67, 59-81. http://dx.doi.org/10.1016/s0378-4290(00)00084-8

Berry, P. M., Sterling, M., Spink, J. H., Baker, C. J., Sylvester-Bradley, R., Mooney, S. J., ... Ennos, A. R. (2004). Understanding and reducing lodging in cereals. Advances Agronomy, 84, 217-271. http://dx.doi.org/10.1016/S0065-2113(04)84005-7

Carter, P. R, \& Hudelson, K. D. (1988). Influence of simulated wind lodging on corn growth and grain yield. Journal of Production Agriculture, 1, 295-299.

Crook, M. J., \& Ennos, A. R. (1993). The mechanics of root lodging in winter wheat, Triticum aestivum L. Journal of Experimental Botany, 44, 1219-1224. http://dx.doi.org/10.1093/jxb/44.7.1219

Crook, M. J., \& Ennos, A. R. (1994). Stem and root characteristics associated with lodging resistance in four winter wheat cultivars. The Journal of Agricultural Science, 123, 167-174. http://dx.doi.org/10.1017/S0021859600068428

Easson, D. L., White, E. M., \& Pickles, S. J. (1993). The effects of weather, seed rate and cultivar on lodging and yield in winter wheat. The Journal of Agricultural Science, 121, 145-156. http://dx.doi.org/10.1017/S0021859600077005

Ennos, A. R., Crook, M. J., \& Grimshaw, C. (1993a). The anchorage mechanics of maize, Zea mays. Journal of Experimental Botany, 44, 147-153. http://dx.doi.org/10.1093/jxb/44.1.147

Ennos, A. R., Crook, M. J., \& Grimshaw, C. (1993b). A comparative study of the anchorage systems of himalayan balsam Impatiens glandulifera and mature sunflower Helianthus annuus. Journal of Experimental Botany, 44, 133-146. http://dx.doi.org/10.1093/jxb/44.1.133

Feix, G., Hochholdinger, F., \& Park, W. J. (2002). Maize root system and genetic analysis of its formation. In: Y. Waisel, A. Eshel, U. Kalfkalfi (Eds.). Plant Roots:The Hidden Half (3nd ed.) (pp. 239-248). New York: Marcel Dekker. 
Feng, G, Liu, Z. F., Li, Y. Y., Jing, X. Q., Xing, J. F., \& Huang, C. L. (2010). Study on the trends in yield change of maize single cross hybrids in different periods in China. Scientia Agricultura Sinica, 43, 277-285. ( In Chinese)

Fouéré, A., Pellerin, S., \& Duparque, A. (1995). A portable electronic device for evaluating root lodging resistance $\begin{array}{llll}\text { in maize. Agronomy } & \text { Journal, }\end{array}$ http://dx.doi.org/10.2134/agronj1995.00021962008700050042x

Girardin, P., Jordan, M. O., Picard, D., \& Terndel, R. (1986). Harmonisation des notations concernant la description morphologique d'un pied de maïs (Zea mays L.). Agronomie, 6, 873-875.

Guingo, E., \& Hébert, Y. (1997). Relationships between mechanical resistance of the maize root system and root morphology, and their genotypic and environmental variations. Maydica, 42, 265-274.

Hébert, Y., Barriere, Y., \& Betholeau, J. C. (1992). Root lodging resistance in forage maize: genetic variability of root system and aerial part. Maydica, 37, 173-183.

Hébert, Y., Guingo, E., \& Loudet, O. (2001). The response of root/shoot partitioning and root morphology to light reduction in maize genotypes. Crop Science, 41, 363-371. http://dx.doi.org/10.2135/cropsci2001.412363x

Hetz, W., Hochholdinger, F., Schwall, M., \& Feix, G. (1996). Isolation and characterization of rtcs, a maize mutant deficient in the formation of nodal roots. The Plant Journal, 10, 845-857, http://dx.doi.org/10.1046/j.1365-313X.1996.10050845.x

Hoppe, D. C., McGully, M. E., \& Wenzel, C. L. (1986). The nodal roots of Zea: their development in relation to structural features of the stem. Canadian Journal of Botany, 4, 2524-2537.

Jedel, P. E., \& Helm, J. H. (1991). Lodging effects on a semidwarf and two standard barley cultivars. Agronomy Journal, 83, 158-161. http://dx.doi.org/10.2134/agronj1991.00021962008300010036x

Kamara, A. Y., Kling, J. G., Menkir, A., \& Ibikunle, O. (2003). Association of vertical root-pulling resistance with root lodging and grain yield in selected $\mathrm{S}_{1}$ maize lines derived from a tropical low-nitrogen population. Journal of Agronomy and Crop Science, 189, 129-135. http://dx.doi.org/10.1046/j.1439-037X.2003.00023.x

Kevern, T. C., \& Hallauer, A. R. (1983). Relation of verital root-pull resistance and flowering in maize. Crop Science, 23, 357-363. http://dx.doi.org/10.2135/cropsci1983.0011183X002300020041x

Melchinger, A. E., Geiger, H. H., \& Schmidt, G. A. (1986). Vertical root-pull resistance and its relationship to root lodging and forage traits in early maturing European inbred lines and F1 hybrids of maize. Maydica, 31, 335-348.

Penny, L. H. (1981). Vertical-pull resistance of maize inbreds and their testcrosses. Crop Science, 21, 237-240, http://dx.doi.org/10.2135/cropsci1981.0011183X002100020008x

Pinthus, M. J. (1967). Spread of the root system as indicator for evaluating lodging resistance of wheat. Crop Science, 7, 107-110. http://dx.doi.org/10.2135/cropsci1967.0011183X000700020005x

Pinthus, M. J. (1974). Lodging in wheat, barley and oats: the phenomenon, its causes, and preventive measures. Advances in Agronomy, 25, 209-263. http://dx.doi.org/10.1016/S0065-2113(08)60782-8

Sposaro, M. M., Chimenti, C. A., \& Hall, A. J. (2008). Root lodging in sunflower. Variations in anchorage strength across genotypes, soil types, crop population densities and crop developmental stages. Field Crops Research, 106, 179-186. http://dx.doi.org/10.1016/j.fcr.2007.12.001

Stamp, P., \& Kiel, C. ( 1992). Root morphology of maize and its relationship to root lodging. Journal of Agronomy and Crop Science, 168, 113-118. http://dx.doi.org/10.1111/j.1439-037X.1992.tb00987.x

Stanca, A. M., Jenkins, G., \& Hanson, P. R. (1979). Varietal responses in spring barley to natural and artificial lodging and to a growth regulator. The Journal of Agricultural Science, 93, 449-457, doi:10.1017/S0021859600038144

Sylvain, P. (1993). Rate of differentiation and emergence of nodal maize roots. Plant and Soil, 148, 155-161. http://dx.doi.org/10.1007/bf00012853

Tetio-Kagho, F., \& Gardner, F. P. (1988). Responses of maize to plant population density. I. Canopy development, light relationships, and vegetative growth. Agronomy Journal, 80, 930-935. http://dx.doi.org/10.2134/agronj1988.00021962008000060018x

Zur, B., Hesketh, J., \& Reid, J. (1992). Temperature effects on nodal root development in maize. Plant and Soil, 142, 151-155. http://dx.doi.org/10.1007/bf00010186 